\title{
Evolution of the lighthouses of Gdansk
}

\author{
A. F. Komorowski \& I. Pietkiewicz \\ History Department, Naval University of Gdynia, Poland
}

\begin{abstract}
The oldest and the biggest Polish port in Gdansk has a very intricate history, which begins in 1000. Located in the delta of the Vistula River, the port has a fully developed infrastructure starting from Nowy Port and Westerplatte, through Motlawa and Martwa Wisla to Gorki Zachodnie and Port Polnocny. The strenuous development of the port started in the 14th and 15th centuries, together with the increase of trans-shipment of wood, grain, pitch, wax and other goods. Because of the continuous increase of turnover and profit from trade, the quickest development of Gdansk took place in the 16th and 17th centuries. At that time approximately 500-1000 vessels called at the port, mainly from the Netherlands and England. From the second half of the 18th century, Gdansk had been under the influence of Prussia, thus the port became one of the Prussian ports. In the years 1919-1939, due to the will of the League of Nations, Gdansk became a Free City. After 1945, there was intensive development of the port and all institutions connected with maritime affairs. During the mentioned period the port was immensely exploited and it demanded good navigational support at the approach and in port channels. In the 15-17th centuries the Wisloujscie (Weichselmünde) Lighthouse directed vessels to the entrance to the harbor; the lighthouse was situated on the right fringe of the Vistula estuary. Later on, the localization of the estuary changed place and thus the navigation signs at the entrance. The new lighthouse was built in 1758 and, together with the front beacon, created a leading mark, which pointed out the new entrance to the port. Modifications of aids to navigation also took place in the following years. The next lighthouses were built in Gdansk in 1894 and 1984.

The history of Gdansk Lighthouses is the main subject of this study. Keywords: maritime heritage, history of navigation, lighthouses.
\end{abstract}




\section{Historical background}

Lighthouses - buildings of a characteristic easily recognizable shape in the daytime and in the nighttime releasing light - have been indicating the way for sailors for hundreds of years. Usually, they were built in the coastal regions where navigation was very problematic and their function was to warn sailors about a possible danger and indicate the correct way.

The first lighthouse, which was sponsored by the Danish King Waldemar II in the 13th century, was the lighthouse on the Falsterbo Cape. The next one was constructed in Trawemünde near Lubek in $1225 \mathrm{r}$.

The history of the lighthouses in Gdansk is also that of a few centuries back. For many years, the Gdansk port has been a main trade center for this part of the Baltic Sea and thus different buildings in different eras were used as lighthouses to ensure safe entry to the port.

The chapters of the turbulent history of the Gdansk lighthouses were eternized by the Teutonic Knights, whose efforts caused the rise of the wooden defense 'blokhaus' in the 14th century. The new structure was not only fulfilling the function of the watch house, but it was also a good orientation point for the sailors and the ships entering the port. Unfortunately, in 1433, it was totally destroyed by the Hussites. The watch house was rebuilt, but in November 1465 it was again destroyed, this time by a heavy storm.

\section{The Weichselmünde Lighthouse - (Wisloujscie)}

In 1482 the watch house was transformed into the oval, brick tower and became the central point of the fortress called 'Weichselmünde'. On the top of the gothic turret was situated a fireplace, where during the night wood and coal were burnt. In that period, the military role of the building declined a lot and the observation of the entrance to the port and indication of the access path became its main purpose. In the 16th century, a three-layered 'chaplet' was constructed around the tower base, which was use for storehouses, casemates, barracks and for the cannon stands.

At the end of the 16th century, engagement of the Stefan Batory's troops against the Gdansk rebels resulted in the total destruction of the tower. The rebuilt tower, reaching 17 meters high, became the central element of the fortress and was crowned with the Italian style high cupola. Candles were used as the light source. They were lit during nightfall from the 24th September to the 24th March. In 1758, the 'Weichselmünde' fortress lost its lighthouse function. The ironic fact was that the reason for turning off the lighthouse, as it can be presumed from its turbulent history, was not the destruction caused by the warfare or the weather anomaly, but the development of sailing and increased importance of Gdansk as a port.

\section{The Neufahrwasser Lighthouse (New Port)}

The shoals, created by the freely carried Vistula's sand, generated a serious danger for bigger ships. The use of the Western Deep from 1724 as the main 


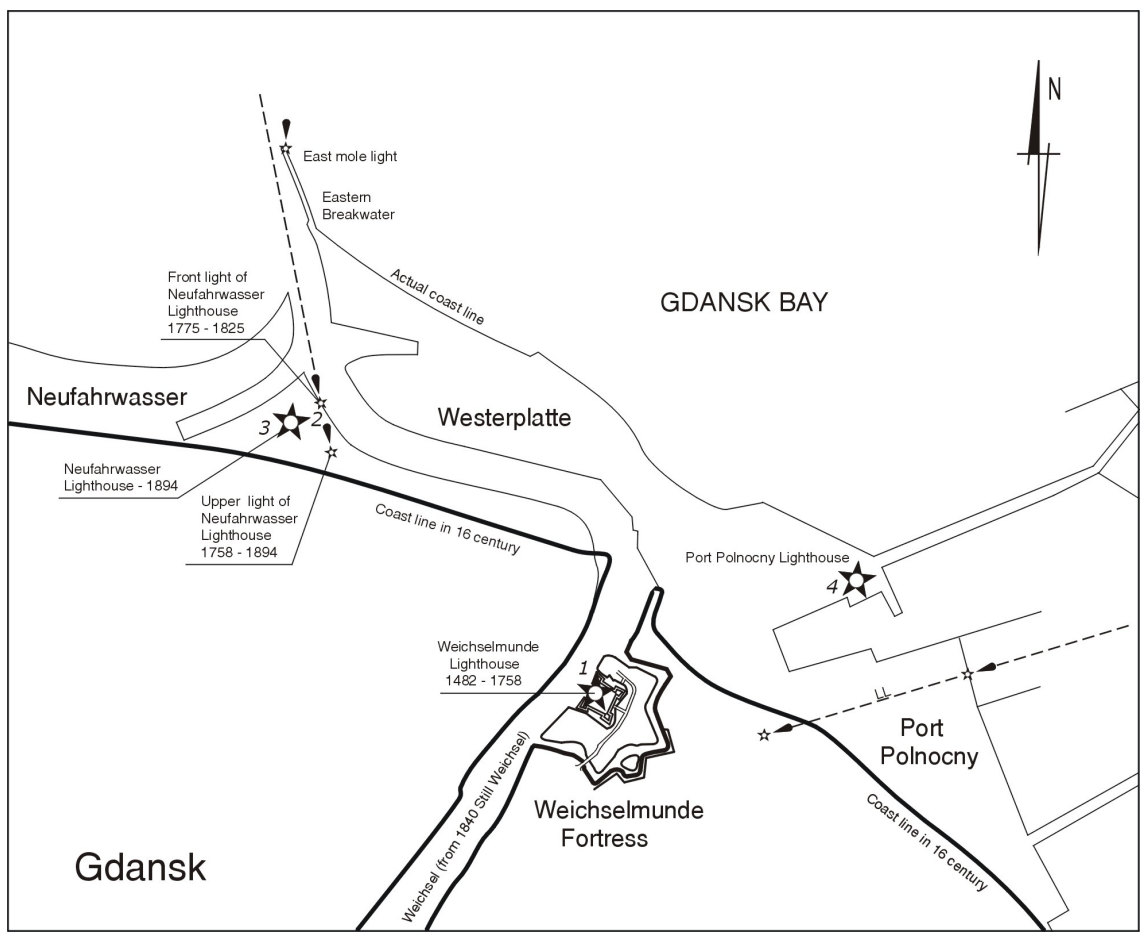

Figure 1: The changes of the entrance fairway to the port of Gdansk in 1594-1805. Source: Internationaler Geografen - Congress, Berlin, 1899.

entrance to the port coerced the local authorities to change the position of the navigation light, which was indicating the entrance fairway (Fig. 1).

In accordance with the Maritime Trade Union, it was decided that the new sea mark would consist of two lights, lower and higher, distanced 75 meters away from each other and that the best place for its location would be the settlement of Brzezno. This project was realized in three years. The changes of the navigation signs for the entrance to the port in Gdansk were announced with adequate notice. On the 24th September 1758 the two new lighthouses were opened. The lower one was the lever lantern. It had a lifted steel basket with lighted coal inside and was built on a round brick platform. Coal was also burned on the top of the 13 meter higher lighthouse (Fig. 2). Both of them formed the so called unit of directional lighthouses, which today can be called leading marks and whose overlapping lights pointed out the correct way towards the port. In 1817 coal was replaced by $5 \mathrm{~cm}$ thick wax candles, because of the increased consumption of coal during the strong winds. Some of the sources claim that, in that period, the round glass-in housing, called the lantern room, which was keeping away the wind from the candle light, was built at the top of the higher tower. Due to the low intensity of the candle light, in January 1819 the wax candles were replaced 


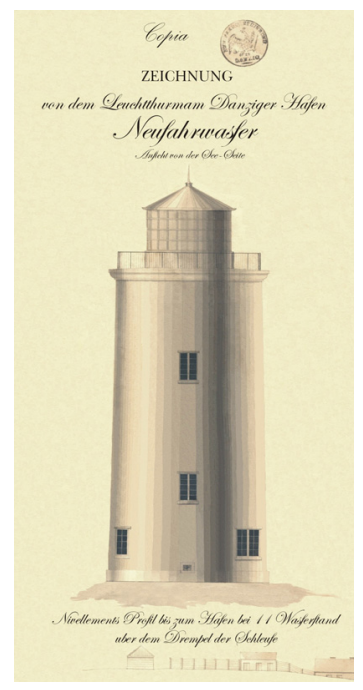

Figure 2: $\quad$ Lighthouse in the Nowy Port, 1828.

by gas. Assembled on the platforms, blowpipes were powered by acetylene gas. That was the situation until 1828. The following change of the entrance to the frequently modernized port, which was based on the extension of the eastern pier, resulted in turning off the lower tower and adding two blowpipes to the higher lighthouse. Then, the subsequent alterations to the lighthouse, which now was called Neufahrwasser (Nowy Port), was based on economic reasons. In 1860 , because of the high costs of maintenance, the blowpipes were substituted by seven Arganda lamps powered by rapeseed oil. However, after 10 years, it was again replaced, this time by crude oil and adequate blowpipes.

Each lamp was equipped with one wick and a parabolic reflector of $53 \mathrm{~cm}$ diameter. The lamps were placed in two semicircular rows one on top of the other. On the top, there were three lamps and on the bottom there were four. In this way the light was visible from 14,5 $\mathrm{Nm}$ distance. The register of navigation lights from 1878 contained detailed information about the lighthouse. Besides the information about the tower, source of the light and the lens technology, the register also included the geographic location data: $54^{\circ} 24^{\prime} 18^{\prime \prime}, \mathrm{N}$ and $18^{\circ} 40^{\prime} 10^{\prime}$ ', E. From the lighthouse description, it was known that the tower was painted with a white color and the lantern with dark green. The last chord of the lighthouse the remains of the directional light - sounded in 1888. Then, famous journals announced sensational news of the installation of the new electric light on the lighthouse, which was powered by daytime steam generators. It was the first lighthouse on the Baltic Sea that was equipped with electric light. The light bulbs were very often replaced to find the most appropriate light parameters. Once, it was the filament lamp, other times the arc lamp. As the result of these changes higher light coverage of 20 miles was reached. 


\section{The new Neufahrwasser Lighthouse (Nowy Port)}

Although the lighthouse has been modernized many times, its light in Hel was almost invisible and with increasing further demands it was decided to build a new tower. In 1894, next to the old lighthouse, a new 4 meter higher tower was built. It was modeled on the lighthouse in Cleveland (Fig. 3), which today no longer exists. The octagon form casing was over $27 \mathrm{~m}$ high and the construction was made out of face brick and based on white sandstone. The new tower also used an electric light, which was powered by the daytime steam generators. This innovatory device, on the Baltic Sea, was used for the first time in Gdansk. On the top of the lighthouse a so called time ball was placed. This mechanism was moved from the wooden tower where it was used from 1876. Every day at 12 o'clock, in response to the signal (telegraph form from the Royal Astronomic Observatory in Berlin), the $70 \mathrm{~kg}$ ball was dropped along the lighthouse pole. The movement and the sound that the ball made signaled to the navigators when to regulate the chronometers.

The accuracy of their work enabled the navigators to set precise geographic longitudes. In 1921, after the opening of the first radio station in Gdansk, the time ball ceased to function. The light created by the lighthouse often changed its characteristics. The most interesting, two-colored light, was created on the 20th

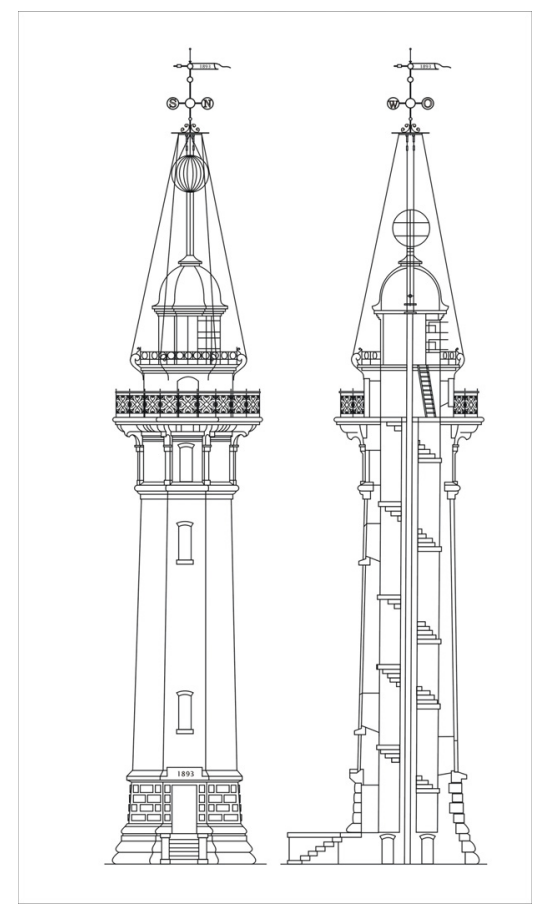

Figure 3: Lighthouse in the Nowy Port - 1894. Source: TU Berlin Architektmuseum, Inv. Nr. 32953. 
October 1911. It was a flashing light: 1 second of the light and a 4 second pause. The angle of the light emission reached $180^{\circ}$ and was divided into five sectors. In the middle and side sector the light had a white color, however in the outer sectors the light was red.

The biggest range, $20 \mathrm{Nm}$, was in the middle sector. In January 1915, for the order of the Emperor's Navy, the head lantern was placed on the top of the lighthouse and on the gallery additional reflector. However, this was not the only military episode in the lighthouse history in the Nowy Port. Until today, marks on the bricked hole, which were caused by artillery projectiles, are visible. The more precise account of that happening was presented in the memories of the commander of the $77 \mathrm{~mm}$ gun, Corporal Eugeniusz Grabowski, one of the Westerplatte defenders. After WWII, the lighthouse was often modernized and the light characteristics were changed many times. This lighthouse was used until 1984, when the modern lighthouse in the port of Polnocny replaced it. In 2001, the wrecked building was bought from the National Treasures, by a Canadian with Polish origins, Stefan Jacek Michalak. After the necessary renovations and conservation of the object, in 2004 - in the 110th anniversary year of the construction of the lighthouse - Michalak has permitted society to visit this historical and cultural monument as the Museum of the World's Lighthouses. The present owner of the lighthouse has managed to realize the plans connected with restoration of the time ball, which was functioning in the lighthouse in the 19th and 20th centuries.

\section{The Port Polnocny Lighthouse}

The history of the youngest lighthouse on the Baltic Sea coast, called "GdanskPort Polnocny", started on the 18th June 1984. The lantern, of this unusual lighthouse construction, was situated right above the harbor master's office, on

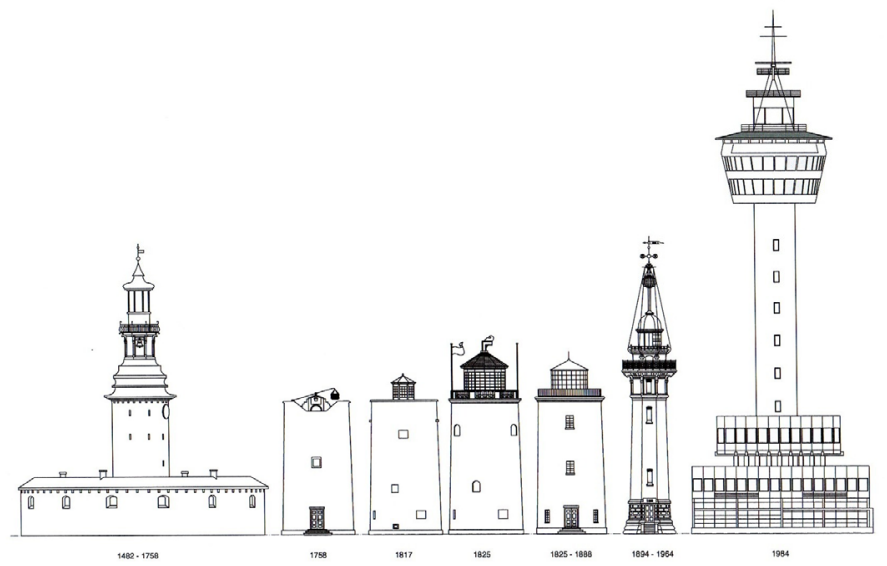

Figure 4: The development of the Gdansk Lighthouses. 
the 56 meter squared blue tower. This lighthouse is part of the honorable heritage of the Gdansk lighthouses. In the glass lantern room, three two-sided PRB panels were installed -21 out of 60 were the reflector bulbs.

They emit light with the power of 1,5 million candelas. For comparison, the last system used in the lighthouse in the Nowy Port emitted 40 thousand candelas. During the night the light of the lighthouse in the Port Polnocny is visible for the distance of 25 Nautical miles.

\section{Conclusion}

The history of the described Gdansk lighthouses was determined by three main factors, which are normally common all around the world. The first one was the development of the marine trade, and related to that the necessity of ensuring a safe entrance to the port. Second was the natural technological development that influenced the progress in the construction of the light generators. The last factor, the most characteristic for the Gdansk lighthouses, was the expansion of the port and the quay. As a result, the location of the lighthouse was often changed.

\section{References}

[1] National Archives in Gdansk, Records Wasserbaudirection Neufahrwasser i Regierung Gdansk.

[2] Berthold F. W., Geschichte von Rugen und Pommern. Hamburg 1839.

[3] Czerner M., Latarnie morskie polskiego wybrzeza. Poznan 1986.

[4] Geheimes Staatsarchiv Preussischer Kulturbesitz Berlin Rep. 93B. Nr. 4807-4808.

[5] Komorowski A.F., I. Pietkiewicz, Historia techniki Nawigacyjnej: Gdanskie latarnie morskie. III Miedzynarodowa Sesja Naukowa Dziejow Ludow Morza Baltyckiego. Wolin 2007.

[6] Veitmeyer L. A., Leutchfeuer und Leuchtapparate. Munchen-Lepzig 1900. 